\title{
«ТОЧКА ОПОРЫ» В ИСТОРИИ \\ ОБЩЕСТВЕННОЙ ЖИЗНИ СИБИРИ: К 150-ЛЕТИЮ Н. А. РОЖКОВА
}

Статья посвящена вопросам участия историка и общественно-политического деятеля Н.А. Рожкова, 150-летие которого отмечалось в конце 2018 г., в сибирских периодических изданиях 1910-1917 гг.

Ключевые слова: Н.А. Рожков, история Сибири, периодическая печать Сибири, РСДРП, меньшевики в Сибири, сибирская ссылка.

T.A. BORISOVA

\section{«POINT OF SUPPORT» IN THE HISTORY OF SOCIAL LIFE OF SIBERIA:}

\section{TO THE $1^{\mathrm{TH}}$ ANNIVERSARY OF N. A. ROZHKOV}

The article is devoted to the participation of the historian and public and political figure N.A. Rozhkov, whose $150^{\text {th }}$ anniversary was celebrated at the end of 2018, in the Siberian periodicals of 1910-1917.

Keywords: N.A. Rozhkov, History of Siberia, Siberian periodicals, RSDLP, Mensheviks in Siberia, Siberian exile.

Осенью 2018 г. исполнилось 150 лет со дня рождения Николая Александровича Рожкова (1868-1927), ученого-историка и политического деятеля, чье имя в первые десятилетия XX в. было связано с Сибирью. Сибирская ссылка Рожкова продлилась семь лет (1910-1917) и, пожалуй, до сих пор является не вполне ясной страницей его биографии. Единственная, из обнаруженных на сегодня посвященных Рожкову юбилейных статей, принадлежит О.В. Волобуеву и Д.А. Гонзалезу [5]. Вышедшая же в 2017 г. монография доктора Д.А. Гонзалеза, директора научного центра Н.А. Рожкова (Новый Южный Уэльс, Австралия) стала первой англоязычной биографией Николая Александровича [43].

Интерес к фригуре Рожкова, как будто, возвращается в последние десятилетия. Однако, простирается он, чаще всего, в двух направлениях. Одно из них - научная стезя Рожкова, незаслуженно забытого историка, автора 12-томного курса «Истории России в сравнительноисторическом освещении (основы социальной динамики)» и ряда других научных трудов. В этой роли он чаще всего рассматривается в ракурсе 
преломления позитивизма в исторической науке (например, у упомянутых выше авторов). Другое направление - политическая деятельность Рожкова-члена РСДРП. И если в 1960-1980-е гг. он оценивался как меньшевик и ликвидатор, то сегодня обрел «популярность» в качестве одного из оппонентов Ленина. В этом ракурсе, однако, чаще говорится о деятельности Рожкова после событий февраля 1917 г., т.е. характеризуется пост-сибирский период его жизни. За кадром остается полная история сибирских периодических изданий с участием Рожкова, а также их общественный и политический резонанс. В данной статье рассматривается указанный аспект сибирской жизни Рожкова-ученого и общественного деятеля, являющийся важным не только для восполнения пробелов в биографии Николая Александровича, но и для воссоздания регионального контекста общественно-политической и хозяйственной жизни Сибири 1910-х гг. в целом. Возвращение к творческому наследию Рожкова 1910-1917 гг. объяснимо актуальностью рассмотрения «региональной составляющей» его жизни, а также его вклада в развитие сибирской политической журналистики.

Несколько сотен газетных и журнальных публикаций Рожкова периода нахождения в ссылке - это одновременно и источниковое, и историографическое наследие, объем и содержание которого еще предстоит уточнять и интерпретировать. Тем не менее, стоит отказаться от прежнего определения данного направления сибирской деятельности Рожкова. Рожков не журналист, по крайней мере, в современном понимании этого слова. Скорее - публицист и талантливый организатор, выступавший редактором и соредактором ряда сибирских изданий, умевший собрать вокруг себя хорошую команду в лице пишущих и мыслящих ссыльных (В.С. Войтинский, Ф.И. Дан, И.Г. Церетели, Н.Ф. Чужак (Насимович) и др.).

В 1910-1914 гг., живя в Иркутской губернии, Рожков принял участие в общей сложности в 13-ти изданиях Восточной и в 3-х - Западной Сибири. В 1915-1917 гг., находясь в гг. Чите, Томске и Новониколаевске - в 6-ти периодических изданиях. Это число подсчитанных на сегодняшний день сибирских изданий с участием Рожкова, возможно, далеко не полное. В связи с тем, что участие политических ссыльных в прессе официально не поощрялось, в сибирской печати он выступает как под своим именем (Н. Рожков, Н.А. Рожков), так и под различными установленными псевдонимами: «Н. Р-ов», «Н.А. Р-ов», «Н.А. Р-В», «Н. Р-В», «Н.Р.», «К. Ломзин», «Я. Наров», «Наров», «Н.». Кроме того, используемые Рожковым псевдонимы «В.А. Войский», «К.Л.», «Н-В», P-ъ» были определены автором данной статьи в процессе изучения его жизни в ссылке, путем анализа сибирских периодических изданий, а также с помощью источников фондов Государственного архива Российской Федерации и Отдела рукописей Российской государственной 
библиотеки [4, с. 5]. Авторство ряда неподписанных передовых (редакционных) статей также может быть отнесено Рожкову, что подтверждается характерной тематикой и терминологией данных публикаций, совокупностью сведений о его деятельности в ссылке, биографическими данными и т.п. [4]. Активная работа Николая Александровича на этом поприще в указанный период объяснима и недостаточно подходящими для научных изысканий условиями, и общей ситуацией в стране. В то же время, сибирский период жизни Рожкова отмечен тем, что общественный резонанс его публицистики превосходил по значимости резонанс его научных работ.

Точкой отсчета для Рожкова здесь становится лето 1910 г., когда по прибытии в Иркутскую губернию он устанавливает сотрудничество с газетой «Восточная заря». В Иркутске 1910 г. существовали две крупные ежедневные газеты: «Сибирь», традиционного областнического, либерального направления, и «Восточная заря», определявшая себя как «прогрессивная, внепартийная газета, уделяющая особое внимание областному отделу и вопросам городского самоуправления» [6].

Условно «издания Рожкова» (те, где он публиковался и/или которые редактировал) можно сгруппировать по нескольким «блокам». Основными темами его статей в первом «блоке» сибирских газет (иркутские «Восточная Сибирь, «Голос Сибири»; «Обская жизнь» г. Новониколаевска, «Сибирское слово» г. Томска, 1910-1911 гг.) являются развитие концепции становления в России «культурного капитализма» (в противовес «хищническому», существовавшему до начала 1900-х гг.), проблемы переселенцев и последствий Столыпинской аграрной политики ${ }^{1}$. В ряде публикаций Рожкова прослеживается связь с его научными трудами предшествующих лет - периода работы в качестве приват-доцента Московского Императорского университета. Часть статей посвящена исследованию развития профеессионального движения, а также демонстрации исторических параллелей в хозяйственном развитии России и Европы. Освещается им и деятельность III Государственной Думы.

В 1911 г. Рожков устанавливает контакты с газетами социал-демократического направления, издававшимися в других (помимо Иркутска) городах: томским «Сибирским словом» и новониколаевской «Обской жизнью». В первом издании он сотрудничает, скорее всего, с целью заработка, публикации здесь не отличаются политической остротой. Статьи в «Обской жизни» носят другой характер. Создавались они, по всей вероятности, во время недолгого пребывания Рожкова в г. Киренске летом 1911 г. Это ряд работ, рассматривавших перспективы отечествен-

${ }^{1}$ Так, например, развитие концепции «культурного капитализма» прослеживается как в подписанных, так и в отдельных неподписанных передовых статьях упомянутых газет. Из чего можно предположить, что авторство их также принадлежит Рожкову. 
ного сельского хозяйства в русле развития «культурного капитализма». Сотрудничество в иркутских газетах «Восточная заря» и, в дальнейшем, в «Голосе Сибири» для Рожкова становится первым этапом участия в сибирской легальной печати. Немаловажным явилось и то, что обе газеты предоставляли ему возможность небольшого заработка в первые месяцы адаптации к условиям местной жизни.

Новая волна публицистов, попавших в сибирскую ссылку в начале 1910-х гг., заметно оживила картину развития периодической печати края, в частности - Иркутской губернии. Слабую жизнеспособность местных демократических изданий того периода нельзя объяснить лишь материальными затруднениями или доминированием в редакциях сотрудников либеральных взглядов. Все эти издания нуждались как в сильном коллективе единомышленников, так и в способном организаторе, что в совокупности обеспечило бы им устойчивый спрос и нужный читательский сегмент. Попытка решения такой задачи была предпринята Рожковым в 1911-1912 гг., когда в общественной жизни Сибири произошел новый всплеск - начало предвыборной кампании в IV Государственную Думу.

Следующий «блок» газет, в которых Рожков выступает уже и как редактор / соредактор - это «Иркутское слово», «Молодая Сибирь» и «Новая Сибирь», издававшиеся поочередно с конца 1911 до начала 1913 гг. В тематике статей Рожкова здесь доминируют три направления: становление «культурного капитализма», выборы в IV Государственную Думу, подготовка к городским выборам. Радикальностью и полемической остротой отличались публикации в «Молодой Сибири», ставшей площадкой социал-демократов в период предвыборной кампании в IV Государственную Думу. В отличие от еженедельного «Иркутского слова» это издание удалось открыть как ежедневное: такой формат давал больше возможностей для освещения местных и российских событий. Название газеты соответствовало мировоззренческой установке Рожкова и его товарищей: пробуждающаяся сибирская молодежь должна была следовать идеалам социал-демократии, отринув идеи областничества и либерализма, выдвинутые в свое время Г.Н. Потаниным, Н.М. Ядринцевым и их сподвижниками. «В одном, однако, молодая Сибирь резко отличается от старой: и старая Сибирь была демократической страной, но демократизм ее был стихийным, бессознательным; теперь пробуждается демократическое сознание, широкие массы начинают сознавать свои интересы и защищать их выдержанно и твердо», - гласит передовица первого номера «Молодой Сибири» [13].

Различные источники, главными среди которых выступают сами комплекты газет, показывают, насколько значительной была роль Николая Александровича в «Иркутском слове» (1911-1912), а затем - в «Молодой Сибири» (1912) и «Новой Сибири» (1912 - нач. 1913). Большая 
личная заинтересованность Рожкова в организации «собственного» социал-демократического издания вполне объяснима: в период ссылки это было практически единственной возможностью косвенного участия в общественно-политической жизни страны для тех, чей статус уже не позволял никаких легальных форм подобной деятельности. Достаточно подробное исследование работы Рожкова в «Иркутском слове» недавно было проведено А.Д. Гонзалезом и О.В. Волобуевым, ранее же проводилось Л.П. Сосновской и Н.Н. Щербаковым [7; 37; 42, с. 180-181].

Оба издания ожидали штрафы, а затем и закрытие. Так, вскоре после проведения выборов в IV Государственную Думу была закрыта «Молодая Сибирь», а ее формальный редактор осужден за дискредитацию работы Иркутской губернской комиссии по выборам. Фактически закрытие данной газеты превратилось в политическое дело уровня губернии [10; 28]. Защитник фрормального редактора, К.Г. Евдокимова, помощник присяжного поверенного В.А. Викер, в своем выступлении на судебном процессе заявил: «Здесь мы имеем дело не с маленьким нарушением закона, а имеем дело с черной грозовой тучей, имеем дело с угрозами реакции. И если у нас есть теперь законодательное учреждение, то этим мы обязаны до некоторой степени и энергии маленьких газет» [39]. Евдокимов был приговорен к заключению на несколько месяцев, а газета закрыта навсегда.

Однако уже менее чем через месяц Рожков с товарищами (Н.Ф. Чужак (Насимович), В.С. Войтинский и др.) открывают ежедневную газету «Новая Сибирь», которая идейно продолжила предыдущую и рассылалась ее прежним подписчикам. Данному изданию в исследованиях прошлых лет не уделялось такого внимания, как «Иркутскому слову» или «Молодой Сибири», поскольку отнесено оно было к сугубо «ликвидаторским» [34, с. 197; 42, с. 170-171]. Что касается публикаций в нем Рожкова, то в основной массе они посвящены проблеме введения в крае земских учреждений, а также некоторым частным вопросам (например, развитию иркутского городского хозяйства). Анализ местных проблем подводил автора к выводам о необходимости распространения на Сибирь общедемократических реформ, что актуализировалось в свете ожидавшихся в конце 1913 г. городских выборов. Однако, если в предыдущих газетах Рожков почти всегда выступает с агитацией (обусловленной предвыборной кампанией) в пользу социал-демократии, то «Новая Сибирь», в силу других редакционных задач, объединяет его разноплановые статьи. В их числе краткий анализ научных публикаций о социальной эволюции рабочих; материал о роли изучения сибирской истории; серия обзорных статей о русско-монгольских отношениях.

«Штрафные» публикации «Молодой Сибири», а также те, что дискредитировали работу комиссии по выборам, писались различными сотрудниками из числа ссыльных. В случае же со штрафованием «Новой 
Сибири» речь шла о неподписанных передовицах, авторство которых с уверенностью можно отнести Рожкову: «Хищнический и культурный капитализм в сельском хозяйстве Сибири» и «Бюрократическое всевластие в сибирской аграрной политике» [9; 26; 27]. В результате, распоряжением Иркутского губернатора, 1 февраля 1913 г. Рожков был выслан в с. Нижнеилимское Киренского уезда, а на следующий день формальный редактор «Новой Сибири», А.П. Маркачев, сделал заявление о приостановлении выпуска газеты [8; 12]1'.

В августе - сентябре 1914 гг. группа ссыльных в лице В.С. Войтинского, И.Г. Церетели, Ф.И. Дана, С.Л. Вайнштейна и др. планирует выпуск собственного издания, на страницах которого должны были найти отражение проблемы военного времени. Уже при подготовке первого сборника стало ясно, что он будет заведомо неподцензурным и обреченным на конфрискацию. В итоге ему был придан вид первого номера журнала, тем более что разрешение на выпуск такого рода повременного издания было получено [3, с. 390-398; 35]. Данный «блок», состоявший всего из двух номеров фрормата журналов, поддерживался фрактическими редакторами - И.Г. Церетели (отвечал за политическое направление) и В.С. Войтинским (литературное редактирование и организационные вопросы) [2, с. 180; 36, с. 84-86]. Весомую роль сыграли Н.Ф. Чужак и Рожков, однако последний, в связи с предстоящим его переездом в Читу, непосредственным редактированием «Сибирского обозрения», скорее всего, не занимался [3, с. 393-398; 15, с. 115; 41, с. 179-180].

История выхода «Сибирского журнала» (10 декабря 1914 г.) и «Сибирского обозрения» (1 января 1915 г.) неоднократно описывалась в воспоминаниях и исследованиях, начиная с 1920-х гг. и до наших дней, а редакционная коллегия изданий получила название «сибирские циммервальдисты». Сами же издания характеризовались как «меньшевистские» и «центристские» или «пацифистско-интернационалистские» ${ }^{2}$ [3, с. 390-391; 11; 14; 15, с. 115; 38; 42, с. 172-173]. В силу широких связей авторов, журналы быстро распространялись по городам Восточной и Западной Сибири, центральной России; попали они и за границу. Причина резонанса обоих сборников становится ясной при рассмотрении понятия антиоборончества, явившего в те дни открытый противоправительственный курс, и вступавшего - в свете изложенного - в конфликт

\footnotetext{
${ }^{1}$ Амнистия по случаю 300-летия дома Романовых позволила А.П. Маркачеву оказаться на свободе, и осенью того же года вновь стать подставным редактором уже еженедельной социал-демократической газеты с аналогичным названием - «Новая Сибирь». Ежедневную (1912 - нач. 1913 гг.) и еженедельную газеты «Новая Сибирь» (1913 г.; далее — «Новое сибирское слово», 1913 г.), к сожалению, нередко путают в исследованиях.

${ }^{2}$ Стоит подчеркнуть, что речь идет о разовом выпуске всего двух номеров изданий, имевших формат журналов по причине того, что разрешение на выпуск такого вида издания уже было получено. Регулярных изданий в виде журналов Рожков, скорее всего, не редактировал и не издавал.
} 
с идеологией основной массы не только «правой», но и либерально-демократической общественности. В практическом отношении репутация изданий поспособствовала тому, что в дальнейшем типографии опасались связываться с известной литературной группой, и запланированный третий номер сборника не вышел.

Статья Рожкова «Война и хозяйство России», опубликованная в «Сибирском журнале», в общих чертах перекликалась с другой его статьей, появившейся впоследствии под аналогичным названием на страницах Санкт-Петербургского журнала «Современный мир» [17; 29]. Значительный интерес представляет и его статья «Россия накануне войны», помещенная «Сибирском обозрении», да и другие публикации данного сборника отличаются (в сравнении с предыдущим) большей широтой, немаловажен и факт расширения круга авторов в сравнении с «Сибирским журналом» [30]. Публикации в данных изданиях демонстрируют очередную «смену вех» у Рожкова: оценивая позицию российской буржуазии на современном этапе, он замечает, что она значительно отличается от позиции довоенной. Оппозиционность крупной буржуазии «старому строю», проявление которой наметилось до войны, стирается из-за усиления ее экономических амбиций (война отбросила назад становление «культурно-капиталистических» отношений) [30].

Надо сказать, что оба журнала на сегодняшний день стали практически библиографической редкостью, тогда как другие Восточно- и Западно-Сибирские издания с участием Рожкова, все-таки, благополучно осели во многих местных и центральных научных библиотеках.

Работа с читинским «блоком» изданий берет отсчет с января 1915 г., когда, согласно Манифесту по случаю 300-летия дома Романовых, Рожков получает право свободного передвижения по Сибири. Сразу после этого он переезжает в Читу, куда был приглашен для редакторской работы в открывшейся в ноябре 1914 г. ежедневной газете «Восточная Сибирь» (инициатором ее создания выступил административно-ссыльный, эсер М.Г. Станиславский). Фактически сотрудничество с читинскими изданиями было начато Рожковым за несколько месяцев до того. С мая 1914 г., в Чите выходит кооперативный журнал «Наше дело» под началом бывшего члена социал-демократической фракции III Государственной Думы А.А. Войлошникова, а на тот момент - председателя правления Областного союза забайкальских кооперативов. Планировавшийся как еженедельник, журнал к лету становится двухнедельным, и, постепенно, доминировавшие на его страницах темы о народном образовании, просвещении, а также хроника местных событий, отходят на второй план. Значительный объем издания теперь занимают статьи, посвященные ключевым проблемам российского и забайкальского народного хозяйства, вопросам кооперации и развитию самодеятельного движения масс. Со сменой редактора, произошедшей в сентябре, журнал теряет 
в объеме, но качественно еще более усиливается. А в октябрьской его книжке появляется первая публикация Рожкова, называвшаяся «Германский капитализм перед войной» [18].

Общероссийские и обще-сибирские вопросы, обозначенные военным временем (в «Восточной Сибири»), проблемы военного времени и развитие кооперативного движения и народного хозяйства (в «Нашем деле») основные темы публицистики Рожкова в читинский период [19; 20]. В соответствующем русле ведутся им и споры с либеральной и кадетской общественностью Забайкалья [23]. За всем этим прослеживается идея усиления общественных организаций и самоуправления для преодоления хозяйственного кризиса и дороговизны, «красной нитью» прошедшая через многие работы Рожкова 1914-1917 гг. Идея, проистекавшая из его модели развития страны при «культурном капитализме», когда легальные общественные организации начнут способствовать определению политического курса и осуществлению демократических реформ.

Журнал «Наше дело» и газета «Восточная Сибирь» были закрыты, повторяя судьбу иркутских изданий, а Рожков привлечен к суду по ч. 1 ст. 132 Уголовного Уложения [16]. В начале октября 1915 г. выходит первый номер еженедельника «Забайкальское обозрение», созданного группой ссыльных социал-демократов. В сравнении с предшествующими, он являет собой еще более политизированное и, скорее, большевистское издание. Рожков же непосредственного участия в работе редакции уже не принимает, так как после судебного разбирательства, в начале же октября, высылается из Забайкалья и переезжает в г. Томск. Сотрудничество с «Забайкальским обозрением» выражается лишь в публикации им в 1915-1916 гг. некоторых статей.

Наладить в Томске практическую работу в местной прессе Рожкову не удалось (хотя отдельные его публикации, все же, появились на страницах местного издания «Сибирский студент» [21; 22]). Не найдя средств и людских ресурсов для создания новой печатной трибуны, он в первой половине 1916 г. вновь посещает Иркутск. А в августе того же года Томскому губернскому жандармскому управлению становится известно о планирующемся в Новониколаевске выходе газеты «Голос Сибири». Направление газеты должна была определять группа лиц, состоящих из эсеров и эсдеков «во главе с Николаем Александровичем Рожковым, который и будет фактическим редактором» [1].

Новониколаевский «Голос Сибири» на рубеже 1916-1917 гг. являлся единственной легальной газетой социал-демократии города, выходившей ежедневно, без каких-либо перебоев, вызванных материальными или цензурными проблемами. Правда, уже в конце 1916 г. у пайщиков газеты, из числа тех самых «культурных капиталистов», возникают сомнения в ее целесообразности: издание давало дефицит, совсем не покрывая расходы [31]. 
Статьи Рожкова в «Голосе Сибири» можно сгруппировать по трем тематическим направлениям: хроника военных событий с краткими комментариями, городские и губернские проблемы в условиях военного времени, работы общетеоретического характера, посвященные социально-политическим и этическим вопросам. Пожалуй, чуть менее яркий, в сравнении с предшествующими «рожковскими» изданиями, «Голос Сибири», однако, оказывается весьма устойчивым, и выдерживает более ста номеров. В обстановке финансовой и политической дестабилизации, на рубеже 1916-1917 гг., отлаженный выход легальной социал-демократической газеты свидетельствовал о хорошо поставленной работе редакции в сочетании с удачно выбранными источниками ее финансирования. В то же время администрация Новониколаевска, в те годы небольшого уездного городка, достаточно лояльно относилась к газетным выступлениям. «Вероятно, только этими причинами, - вспоминал товарищ Рожкова, Н.И. Тетерин, - и можно было объяснить тот фракт, что газета «Голос Сибири» выходила без перерыва больше 6 месяцев. К моменту революции ее тираж выражался в количестве около 4000 экземпляров. Для провинциальной газеты такой тираж надо считать большим» [40, с. 188]. Для сравнения, читинская ежедневная «Восточная Сибирь» выдержала, в общей сложности, 121 номер, после чего была закрыта.

Исследовательская работа с номерами «Голоса Сибири» еще предстоит, так как вопросы редакторской деятельности в ней Рожкова, равно как и деятельности сотрудников газеты в целом еще недостаточно изучены ${ }^{1}$. В феврале 1917 г. Новониколаевский «Голос Сибири» одним из первых в регионе размещает на своих страницах оперативную информацию о событиях в Петрограде, об изменениях внешней и внутренней обстановки [33]. Газета просуществовала до конца 1917 г., отдельные материалы в нее по-прежнему присылал Рожков, уехавший в конце марта в Москву, а затем в Петроград.

Воздействие описанных в данной статье изданий на сибирскую общественность, их собственная история, как своего рода «производственных площадок» ссыльных (и агитационных площадок тоже), реакция на них местного населения - все это представляет собой поле для последующих возможных исследований. Фактически Рожкову в сибирской социал-демократической прессе 1910-1917 гг. принадлежала роль политического обозревателя, соответственно, его статьи, так или иначе затрагивавшие вопросы реформирования государственного устройства, во многом определяли общее политическое направление изданий.

${ }^{1}$ В конце 1920-х гг., когда Н.И. Тетерин собрался писать работу о Рожкове, его вдова, М.К. Рожкова, передала часть материалов из личного архива Николая Александровича. Однако ни работу, ни материалы опубликовать не удалось: все документы пропали после ареста Н.И. Тетерина в середине 1930-х гг. Сам Н.И. Тетерин прибыл в Новониколаевск из Иркутска 15 августа 1916 г., включившись в работу в «Голосе Сибири» с первых же номеров [32]. 
За всем этим тянется цепочка полузабытых имен, нераскрытых псевдонимов, неясных поступков самих публицистов, иногда - непрозрачных действий органов власти и должностных лиц. Привлекательность Рожкова усиливается тем, что его фиигура - и здесь невозможно удержаться от игры слов - взятая за «точку опоры» ${ }^{1}$, помогает воссоздать общий контекст эпохи, общественную жизнь Сибири последних предвоенных и предреволюционных лет. Кроме того, публицистическое наследие Рожкова выступает богатой источниковой базой не только в части истории идей и политических партий, но и в части истории хозяйства, экономической и политической регионалистики. С другой стороны, история отдельных сибирских периодических изданий рассматриваемого периода, как общественно-политических «площадок», имевших свои концепции и фриксировавших изменчивость социально-экономических и иных процессов в региональном контексте, позволит изучить и региональную политическую журналистику 1910-1917 гг.

\section{Список использованной литературы и источников}

1. Агентурные сведения г. Томск // Государственный архив Российской Федерации. - Ф. 102. - ДП ОО. - 1916. - ОП. 246. - Д. 5. - Ч. 81. - Лит. Б. - Л. 5.

2. Вельман В. Февральская революция в Сибири / В. Вельман // Пролетарская революция. - 1925. - № 3. - С. 167-200.

3. Войтинский В. С. Годы побед и поражений / В. С. Войтинский. - Кн. 2 : На ущербе революции. - Берлин : Изд-во Гржебина, 1924. - 411 с.

4. Возвращенная публицистика: указатель публикаций Н.А. Рожкова в сибирских периодических изданиях 1910-1917 гг. / авт.-сост. Т. А. Борисова ; науч. ред. Н. Н. Щербаков. - Иркутск : Изд-во БГУ, 2003. - 87 с.

5. Волобуев О. В. Николай Александрович Рожков. К 150-летию со дня рождения / О. В. Волобуев, Д. А. Гонзалез // Вестник Московского государственного областного университета. Серия: История и политические науки. - 2018. № 5. - С. 61-77.

6. Восточная заря. $-1910 .-29$ июня. - (Без. подп.).

7. Гонзалез Д. А. Н. А. Рожков в сибирской ссылке и газета «Иркутская слово» (май 1910 - январь 1912 гг.) / Д. А. Гонзалез, О. В. Волобуев // Вестник Московского государственного областного университета. Серия: История и политические науки. - 2018. - № 2. - С. 6-24.

8. Городская хроника. Административные вести // Сибирские вести. 1913. - 1 февр.

9. Городская хроника. Административные вести // Сибирские вести. 1913. - 9 февр. 25 дек.

10. Дело редактора газеты «Молодая Сибирь» // Новая Сибирь. - 1912. —

11. Левин Ш. М. Социалистическая печать во время империалистической войны / Ш. М. Левин // Красный архив. - 1922. — № 2. - С. 200-225.

1 Две концептуальные статьи Н.А. Рожкова, выходили с одинаковым названием «Точка опоры». Первая - в мае 1911 г. в Петербургской «Звезде», вторая - в августе 1911 г., в Новониколаевской «Обской жизни» [24; 25]. За одинаковым названием скрывались, по сути, две различные работы. 
12. Маркачев А. П. Письмо в редакцию / А. П. Маркачев // Сибирские вести. - 1913. - 3 февр.

13. Молодая Сибирь // Молодая Сибирь. - 1912. - 19 сент. - (Без. подп.).

14. Ненароков А. П. «Сибирские марксисты» об экзамене революцией 1905 года / А. П. Ненароков // Россия XXI. — 2017. — № 3. - С. 168-191.

15. Николаев В. И. Сибирская периодическая печать и политическая ссылка / В. И. Николаев // Каторга и ссылка. - 1928. - № 6. - С. 96-122.

16. «Обвинительный акт» и другие материалы следственного дела Н. А. Рожкова // Российская государственная библиотека. Отдел рукописей (ОР РГБ). Ф. 546 (Рожков Н. А.). - Оп. 1. - Карт. 1. - Ед. хр. 4. - Л. 2.

17. Рожков Н. Война и хозяйство России / Н. А. Рожков // Современный мир. - 1915. - № 10. - Отд. 2. - С. 74-98.

18. Рожков Н. Германский капитализм перед войной / Н. А. Рожков // Наше дело. - 1914. - № 19/20. - С. 5-7.

19. Рожков Н. Влияние войны на денежное обращение в России / Н. А. Рожков // Наше дело. - 1914. - № 24. - С. 2-5.

20. Рожков Н. Очередная задача русской кооперации / Н. А. Рожков // Наше дело. - 1915. — № 2. - С. 2-4.

21. Рожков Н. Исторический эскиз / Н. А. Рожков // Сибирский студент. 1915. — № 1/2. - С. 83-88.

22. Рожков Н. К открытию народного университета / Н. А. Рожков // Сибирский студент. - 1915. - № 3/4. - С. 23-28.

23. Рожков Н. Кооперация и ее опекуны / Н. А. Рожков // Восточная Сибирь. $-1915 .-16$ янв.

24. Рожков Н. Точка опоры / Н. А. Рожков // Звезда. - 1911. - 7 мая. № 21. - C. 10.

25. Рожков Н. Точка опоры / Н. А. Рожков // Обская жизнь. - 1911. - 6 авг.

26. Рожков Н. А. Хищнический и культурный капитализм в сельском хозяйстве Сибири / Н. А. Рожков // Новая Сибирь. - 1913. - 30 янв. - (Без. подп.).

27. Рожков Н. А. Бюрократическое всевластие в Сибирской аграрной политике / Н. А. Рожков // Новая Сибирь. - 1913. - 31 янв. - (Без. подп.).

28. Рожков Н. А. Письма к Рожковой 3. П. / Н. А. Рожков // ОР РГБ. - Ф. 546 (Рожков Н. А.). - Оп. 1. - Карт. 22. - Ед. хр. 14.

29. Рожков Н. А. Война и хозяйство России / Н.А. Рожков // Сибирский журнал. - 1914. — № 1. - Стб. 21-30. - (Подп.: Наров).

30. Рожков Н. А. Россия накануне войны / Н.А. Рожков // Сибирское обозрение. - 1915. - № 1. - Стб. 23. - (Подп.: Наров).

31. Рожкова М. К. Жизнь в Москве, 1924-1927 гг.: (Воспоминания) / М. К. Рожкова // ОР РГБ. - Ф. 546 (Рожков Н.А.). - Оп. 2. - Карт. 25. - Ед. хр. 3. - Л. 6.

32. Рожкова М. К. Жизнь в Москве, 1924 - 1927 гг.: (Воспоминания) / М. К. Рожкова // ОР РГБ. - Ф. 546 (Рожков Н.А.). - Оп. 2. - Карт. 25. - Ед. хр. 3. - Лл. 41-43.

33. Роспуск Думы и Совета // Голос Сибири. - 1917. - 2 марта. (Без. подп.).

34. Русская периодическая печать (1895 - октябрь 1917): справочник / авт.сост. Черепахов М. С., Фингерит Е. М. - М. : Госполитиздат, 1957. - 351 с.

35. С разной перепиской о цензуре // Государственный архив Иркутской области. — Ф. 25. - Оп. 10. - Д. 1257. - Лл. 154, 161. 
36. Соколов В. Н. Партбилет №0046340: (Записки старого большевика) / В. Н. Соколов. - Ч. 3 : Сибирь - демократическая страна. - М. : Изд-во Всесоюз. общ-ва полит. каторжан и ссыльнопоселенцев, 1935. - 365 с.

37. Сосновская Л. П. Участие политических ссыльных в «Иркутском слове» (1911-1912) / Л. П. Сосновская // Ссыльные революционеры в Сибири (XIX в. февраль 1917 г.). - Иркутск : Изд-во ИГУ, 1980. — Вып. 5. - С. 84-116.

38. Сосновская Л. П. Участие политических ссыльных в издании «Сибирского журнала» и «Сибирского обозрения» / Л. П. Сосновская // Ссылка и общественно-политическая жизнь Сибири XVIII - начало XX в. - Новосибирск : Наука, 1978. - С. 92-109.

39. Судебная хроника: (Итоги избирательной кампании в г. Иркутске) // Сибирские вести. - 1913. - 3 февр.

40. Тетерин Н. Мои встречи с Н.А. Рожковым / Н. Тетерин // Каторга и ссылка. - 1927. — № 3. - С. 183-189.

41. Чужак Н. Рожков в ссылке: («Статейный список») / Н. Чужак // Каторга и ссылка. - 1927. — № 3. - С. 172-183.

42. Щербаков Н. Н. Влияние ссыльных пролетарских революционеров на культурную жизнь Сибири (1907-1917) / Н. Н. Щербаков. - Иркутск : Изд-во ИГУ, 1984. - 244 c.

43. Gonzalez J. An Intellectual Biography of N. A. Rozhkov: Life in a Bell Jar / J. Gonzalez. — Leiden : Brill Publishers, 2017. — 379 p.

\section{Информация об авторе}

Борисова Татьяна Александровна - кандидат исторических наук, доцент, кафедра менеджмента и государственного и муниципального управления, Санкт-Петербургский университет технологий управления и экономики, 190103, г. Санкт-Петербург, Лермонтовский пр., 44 A; e-mail: umteborisova@gmail.com

\section{Author}

Tatiana A. Borisova - PhD in History, Associate Professor, Department of Management and State and Municipal Government, St. Petersburg University of Management and Economics Technologies, 44 A Lermontovskii Avenue, 190103, St. Petersburg, Russia; e-mail: umteborisova@gmail.com 